\title{
Patent foramen ovale-management challenges: a case series
}

\section{CAlma Sijamija1*, CNermir Granov ${ }^{2}$, DAlma Agačević', Domer Perva², (1) Nedžad Hadžić}

'Travnik General Hospital, Travnik, Bosnia and Herzegovina

${ }^{2}$ Clinical Center University of Sarajevo, Sarajevo, Bosnia and Herzegovina

\author{
KEYWORDS: patent foramen ovale, management. \\ CITATION: Cardiol Croat. 2019;14(3-4):92-3. | https://doi.org/10.15836/ccar2019.92
}

*ADDRESS FOR CORRESPONDENCE: Alma Sijamija, J.U. Bolnica Travnik, Kalibunar bb, 72270 Travnik, Bosna and Herzegovina. / Phone: +387-61-780-085 / E-mail: alma.sijamija@hotmail.com

ORCID: Alma Sijamija, http://orcid.org/0000-0003-2818-0501 • Nermir Granov, http://orcid.org/0000-0002-6228-6230 Alma Agačević, http://orcid.org/0000-0003-4671-0991 • Omer Perva, http://orcid.org/0000-0003-2645-1558 Nedžad Hadžić, http://orcid.org/0000-0002-7186-7803

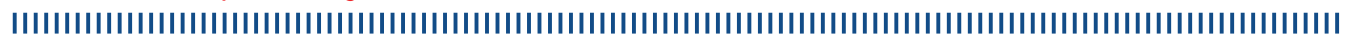

Background: Patent foramen ovale (PFO) is an anatomical interatrial communication with potential for right-to-left shunt. It is detected in $10-15 \%$ of the population by transthoracic echocardiography (TTE) and up to $27 \%$ by autopsy. Most patients with isolated PFO are asymptomatic. Patients may have a history of stroke or transient ischemic event of undefined etiology. ${ }^{1,2}$ The recurrence rate of stroke or TIA has been reported to be as high as 3.4-3.9\% per year. In patients with atrial septal aneurysm and $\mathrm{PFO}$, the risk of first recurrent stroke within 2 years has been reported to be as high as $9 \%$, whereas the rate of subsequent stroke or TIA recurrence within 2 years increases to $22 \%$. No consensus exists on treatment of PFO in patients with transient ischemic attack (TIA) or stroke. Traditional treatment has been antiplatelet therapy alone in low-risk patients or combined with warfarin in high-risk individuals to prevent cryptogenic stroke. , $^{3,4}$

Case report: We represent three cases of PFO diagnosed in our hospital within past 14 months. Case 1: 34-year-old man hospitalized at the Neurology Department due to transient loss of consciousness. Echocardiography showed interatrial septal aneurysm, and two septal defects - subaortal, $11 \mathrm{~mm}$ in diameter with left-to-right shunt and second one, $3 \mathrm{~mm}$ in diameter. There was also visible smaller thrombotic mass in left auricle. Patient underwent surgical closure. Case 2: 39-year-old woman presented at the routine echocardiographic examination after she was discharged from Neurology department where she was treated for stroke. Her brain MRI showed multiple ischemic infarctions with no focal deficit on neurological examination. TTE showed small PFO, $3 \mathrm{~mm}$ in diameter with right-to-left shunt (Figure 1, Figure 2). Patient received percutaneous surgical closure. Case 3: 63-year-old man presented to the internist after loss of consciousness. ECG showed atrial fibrillation and TTE was subsequently performed. It showed atrial
RECEIVED:

February 28, 2019

ACCEPTED:

March 24, 2019

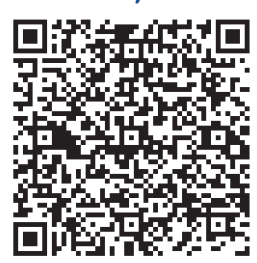

$\square$ Cardiologia Croatica 2019;14(3-4):92.
10. hrvatski dvogodišnji ehokardiografski kongres s međunarodnim sudjelovanjem $10^{\text {th }}$ Croatian Biennial Echocardiography Congress with International Participation Poreč, 16. do 18.5.2019. 
septal aneurysm, a septal defect, 14mm in diameter with left-to-right shunt (Figure 3, Figure 4). The patient is on the waiting list for surgical treatment.
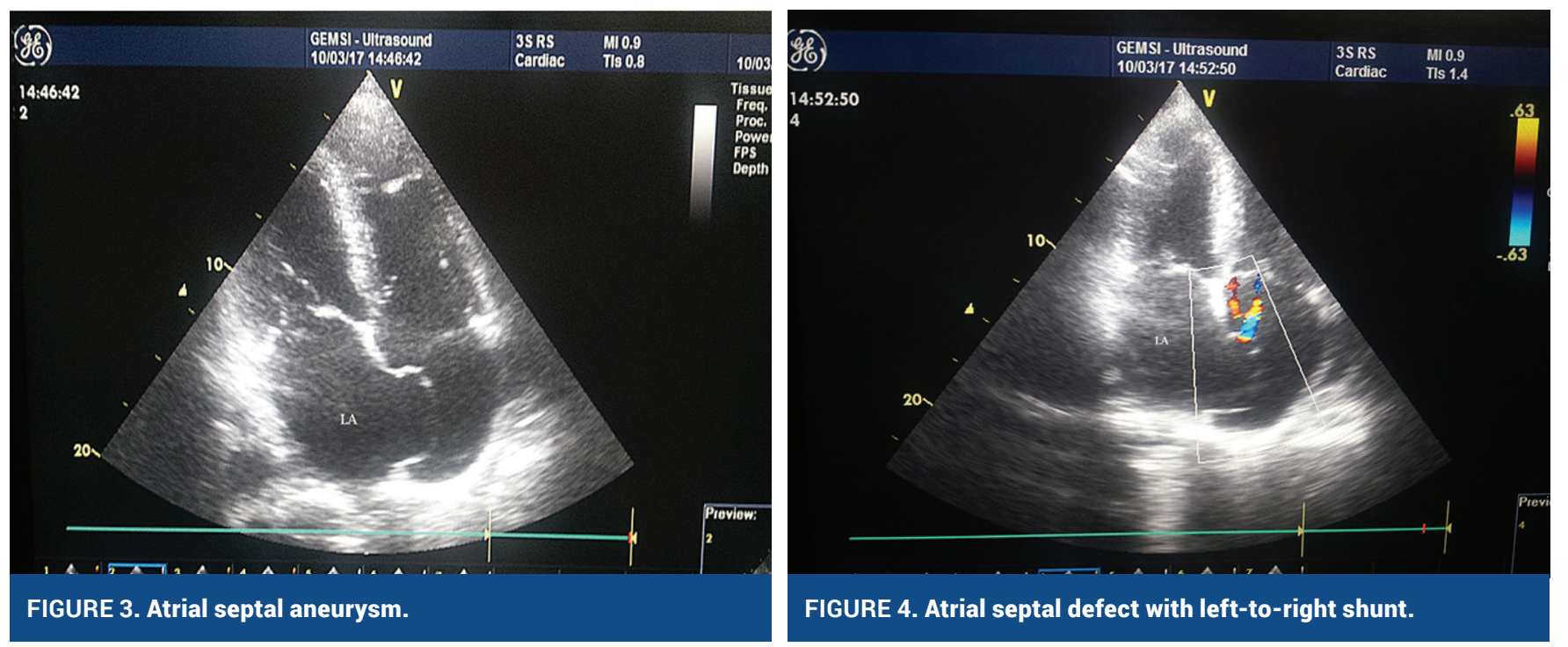

Conclusion: Surgical closure PFO has resulted in elimination of residual shunt across the PFO. Advantages include the following: permanent closure of the defect, prevents future paradoxical emboli, no long-term anticoagulation and its risks.

LITERATURE IIIIIIIIIIIIIIIIIIIIIIIIIIIIIIIIIIIIIIIIIIIIIIIIIIIIIIIIIIIIIIIIIIIIIIIIIIIIIIIIIIIIIIIIIIIIIIIIIIIIIIIIIIIIIIIIIIIIIIIIIIIIIIIIIIIIIIIII

1. Hagen PT, Scholz DG, Edwards WD. Incidence and size of patent foramen ovale during the first 10 decades of life: an autopsy study of 965 normal hearts. Mayo Clin Proc. 1984 Jan;59(1):17-20. https://doi.org/10.1016/S0025-6196(12)60336-X

2. Bonati LH, Wetzel SG, Kessel-Schaefer A, Buser P, Lyrer PA, Engelter ST. Diffusion-weighted imaging findings differ between stroke attributable to spontaneous cervical artery dissection and patent foramen ovale. Eur J Neurol. 2010 Feb;17(2):307-13. https://doi.org/10.1111/j.1468-1331.2009.02805.x

3. Steenblik MH, Mineau GP, Pimentel R, Michaels AD. Population-based assessment of familial inheritance and neurologic comorbidities among patients with an isolated atrial septal defect. Congenit Heart Dis. 2009 Nov-Dec;4(6):459-63. https://doi.org/10.1111/j.1747-0803.2009.00340.x

4. Dalen JE, Alpert JS. Cryptogenic strokes and patent foramen ovales: what's the right treatment? Am J Med. 2016 Nov;129(11):1159-1162. https://doi.org/10.1016/j.amjmed.2016.08.006 